\title{
IMAGINE ALL THE PEOPLE: THE POPULIST AND ANTI-POPULIST DISCOURSES OF SERBIAN AND CROATIAN PROTESTS (2017-2020)
}

\author{
EWA WRÓBLEWSKA-TROCHIMIUK
}

INSTITUTE OF SLAVIC STUDIES, POLISH ACADEMY OF SCIENCES

\begin{abstract}
The aim of this article is to analyze the anti-populist and populist elements in the visual language of selected political manifestations. Protests in Serbia from 2017 to 2020 (mass demonstrations and one individual act of resistance) and in Croatia from 2018 to 2020 were chosen as examples. The article draws on visual materials from the demonstrations and their media coverage. The paper tracks different strategies for visualizing populist and anti-populist rhetoric. It presents various types of the visual discourse of populism: the discourse of the masses, the discourse of polarization, the discourse of vulnerability, and the discourse of the gallows.
\end{abstract}

Keywords: protest; populism; anti-populism; visual discourse analysis; Serbia; Croatia

DOI: $10.14712 / 23363231.2022 .3$

\section{Introduction}

The year 2000 in Croatia and Serbia stands as a political milestone in the history of the two countries. Their transformation, which began in 2000 , increased the level of conflict in the public sphere and invested it with political significance.

This work was supported by a grant from the National Science Centre, Poland (decision no. 2018/31/D/HS2/03127).

Ewa Wróblewska-Trochimiuk, Ph.D. is Assistant Professor at the Institute of Slavic Studies, Polish Academy of Sciences. Address correspondence to her at the Institute of Slavic Studies, Polish Academy of Sciences, Bartoszewicza 1b/17, 00-337 Warszawa, Poland. E-mail: ewa.wroblewska@ ispan.waw.pl. 
New social actors built their legitimacy on the organization of mass protests and collective acts of resistance to the status quo. The period since 2000 in both countries has been a true laboratory for the study of social movements, their political practices, and the language they use, including their visual language. It was a time when a hegemonic culture of new rulers was being formed. However, political struggle and resistance in the streets was directed against a hegemony that had yet to fully define itself. ${ }^{1}$ The rise of resistance can be construed as the moment a society in the process of transformation is founded, ${ }^{2}$ the moment when the demos speaks, reveals itself, and redefines a community. In Croatia and Serbia, creating a visual articulation of resistance was a kind of political and social praxis, and an actualization of the potential of Croatian and Serbian citizenship in the public square.

In 2017, right after presidential elections in Serbia, masses of disgruntled people took to the streets of Belgrade. One of their main slogans, written on placards and used on the internet as a hashtag, was Počelo je [It Has Started]. This short expression indicated that an important, irreversible process had just started before our eyes. In some circles, it was even called a revolution. The protests were compared to the so-called October Revolution of 2000 that led to the dismissal of Serbian president Slobodan Milošević. What started was not only a wave of public disagreement with government policy, but also the construction of a new political subject: the people. The process of bringing this new subject into existence raises the question whether it was in any way related to the phenomenon of populism, and whether populism influenced the politics of the people.

The aim of this paper is to analyze the populist and anti-populist elements of the visual language of political protest in Croatia and Serbia after 2000. One of the most important fields of revolutionary activity is the production and dissemination of images for use in the public sphere. This study analyzes the visual language of the protests and presents the images and slogans they used to visualize and express anti-populism. Moreover, it also considers whether anti-populist demonstrations (consciously or not) adopted populist visual rhetoric, images and slogans.

1 Ernesto Laclau and Chantal Mouffe, Hegemony and Socialist Strategy: Towards a Radical Democratic Politics (London and New York: Verso, 2001), 47-91.

2 T. V. Reed, The Art of Protest: Culture and Activism from the Civil Right Movement to the Streets of Seattle (Minneapolis: University of Minnesota Press, 2005), xiii-xxiii. 


\section{Populism: A Mode of Articulation}

Populism today is one of the most exploited areas of politics, both in theoretical and practical terms. Used in all kinds of phrases in all kinds of contexts, the term "populism" has become a keyword in the modern political lexicon, a weapon wielded by opposition movements, and a nightmare for the elites. In common usage, the original meaning of the term has become blurred, but it is mainly used in political discourse to discredit an opponent. The terms "populism" and "populist" have taken on an unequivocally negative connotation.

The first academic study of populism was entitled Populism: Its Meaning and National Characteristics. ${ }^{3}$ Its publication followed a conference at the London School of Economics, held in 1967 under the title "To Define Populism." Scholars representing various disciplines and different theoretical approaches found it difficult to agree on a definition of the concept. However, they identified a certain set of features that are characteristic of it that invoke the idea of the people and the will of the people in postulates and rhetoric. In a nutshell, these elements include the following: distrust of the authorities, who are perceived to be in a state of inertia, and recognizing the will of the people as morally superior to other political forces; ${ }^{4}$ anti-establishment sentiment and a tendency to escalate tensions between the people and the elite; 5 constructing an identity founded on the idea of "the heartland," an idealized socio-cultural entity; ${ }^{6}$ anti-intellectualism and an appeal to the collective wisdom of the people; $;^{7}$ and strong, charismatic leadership and a mythical bond between the populist leader and the masses. ${ }^{8}$ Populism is characterized by lack of ideological precision stemming from the absence of an ideological core ${ }^{9}$ and an attendant chameleonic nature that lends itself to being freely adapted for various ideological projects. Populism therefore produces socio-political movements rather than structured political parties. ${ }^{10}$ It appears in social

${ }^{3}$ Ghita Ionescu and Ernest Gellner, eds., Populism: Its Meaning and National Characteristics (London: Weidenfeld and Nicolson, 1969).

${ }^{4}$ Peter Wiles, “A Syndrome, Not A Doctrine: Some Elementary Theses on Populism," in Populism: Its Meanings and National Characteristics, ed. Ghita Ionescu and Ernest Gellner (London: Weidenfeld and Nicolson, 1969), 166.

${ }^{5}$ Margaret Canovan, Populism (London: Junction Books, 1981).

6 Paul Taggart, Populism (Buckingham and Philadelphia: Open University Press, 2000).

7 Wiles, “A Syndrome, Not A Doctrine," 166.

8 Ibid., 167.

9 Ibid., 166-179.

${ }^{10}$ Kenneth Minogue, "Populism as a Political Movement," in Populism: Its Meanings and National Characteristics, ed. Ghita Ionescu and Ernest Gellner (London: Weidenfeld and Nicolson, 1969), 197-211. 
groups that "have become aware of being peripheral to centers of power" 11 and that suffer from a crisis of representation.

The literature on populism has been constantly growing in the last decades. Each attempt to define the phenomenon proceeds from a different perspective. Although those perspectives may complement each other, none by itself offers a comprehensive description of populism. For example, Margaret Canovan has created a complex typology of populisms, ${ }^{12}$ but her work was later questioned by Ernesto Laclau, who perceived it as only "a map of the linguistic dispersion that has governed the uses of the term 'populism."'13

The analysis in this article makes use of all of the elements mentioned above. It is also propelled by Ernesto Laclau's observation that populism is a mode of articulation. According to him, "populism is an ontological and not an ontic category - i.e., its meaning is not to be found in any political or ideological content that describes the practices of any particular group, but in a particular mode of articulation of whatever social, political or ideological content." ${ }^{14}$ In other words, populism is a political logic that is embedded in the functioning of every community. Its logic does not seem marginal or extreme to the community; moreover, it is an inherent feature of democratic systems. It can organize any social content, but it is not the content itself. Populism cannot be linked to one isolated phenomenon because it runs across many social phenomena. In his book-length study, On Populist Reason, Laclau defines populism as a discursive strategy that involves creating a political division of society into two camps and calls upon the "underdog" to mobilize against the "dominant group." 15 Thus, he does not consider populism to be an ideology, some particular programmatic content, or even a political project, but a way of doing politics.

In this study, I analyze the communicational aspects of populism. Populism is a kind of discourse: a set of linguistic and non-linguistic practices that constitute a structure of social relations. ${ }^{16}$ So, in a sense, it is a form of Wittgenstein's concept of language games, which contain language exchange and simultaneous action. It is worth noting that discourse is not epiphenomenal in relation to ideas. Its function is not only to express social reality. It also has a performative

\footnotetext{
11 Angus Stewart, “The Social Roots," in Populism: Its Meanings and National Characteristics, ed. Ghita Ionescu and Ernest Gellner (London: Weidenfeld and Nicolson, 1969), 181.

12 Canovan, Populism, 4-13.

13 Ernesto Laclau, On Populist Reason (London: Verso, 2005), 7.

14 Ernesto Laclau, Post-Marxism, Populism and Critique (London Routledge, 2015), 153.

15 Laclau, On Populist Reason, 87.

${ }^{16}$ Laclau and Mouffe, Hegemony and Socialist Strategy, 105-114.
} 
character: the power to disarm an elite and create a political movement. By adopting Laclau's broader view of populism, I consider populist rhetoric to be a "tactical device" 17 for attracting public support. In that way, I develop insights into populism as a political communication style used by different political actors. ${ }^{18}$ As Jan Jagers and Stefaan Walgrave argue, "these political actors can be politicians and political parties, but also movement leaders, interest group representatives, and journalists" who promote a "communication frame that appeals to and identifies with the people, and pretends to speak in their name." 19 In my research, the focus is on visual political practices. This allows me to decode the populist rhetoric in images produced by the participants in many different manifestations and acts of disagreement. The micro-scale of populist rhetoric is at the center of this study. It is a tool for the temporary mobilization of the masses as well as a mode of visual articulation for people's political interests.

Protests as such naturally display populist features. The aim of populist rhetoric is to lead the masses into the streets, manifest an anti-establishment mood, and voice the masses' disagreement with the political forces in power. Protests stem from collective discontent and often produce collective emotions in a crowd. Protests are all to some extent a consequence and an extension of what Chantal Mouffe calls "the populist moment." 20 That moment arises when, under the pressure of political or socio-economic change, the dominant hegemony is destabilized by multiple demands that have not been satisfied. The social basis of the hegemonic formation crumbles and an opportunity arises for the construction of a new subject to take collective action - the people.

\section{Examining Constellations}

For the purposes of this article, I have chosen mass manifestations in Serbia (in 2017 and 2018-2020) and in Croatia (2018-2020). My key selection criteria were the place and time the protests took place: in the capital cities of both

17 Jan Jagers and Stefaan Walgrave, "Populism as Political Communication Style: An Empirical Study of Political Parties Discourse in Belgium," European Journal of Political Research 46, no. 3 (2007): 319-345, doi: 10.1111/j.1475-6765.2006.00690.x; Benjamin Moffitt, The Global Rise of Populism: Performance, Political Style, and Representation (Stanford: Stanford University Press, 2016); Michael Kazin, The Populist Persuasion: An American History (New York: Basic Books, 1995).

18 Jagers and Walgrave, "Populism as Political Communication Style," 322.

19 Ibid., 322.

20 Chantal Mouffe, For a Left Populism (London: Verso, 2018), 12-18. 
countries, Belgrade and Zagreb, between 2017 and 2020. In the middle of the 2010s, populist feelings erupted on the global political scene. ${ }^{21}$ They also affected Croatian and Serbian culture. The protests in the second half of the 2010s provided research material for studying the phenomenon of populism, which appears at various levels of social communication.

In the case of Belgrade, the material I analyzed comes from demonstrations against President Aleksandar Vučić. In the case of Croatia, it comes from manifestations against the capital city Zagreb's mayor, Milan Bandić. In order to show the variety of expressions of anti-populist sentiment, I included one example from a media campaign in my analysis. Although it was an advertising campaign for a film, it does not much differ from the other materials because it had a political subtext.

My analysis is divided into two parts. The first part is devoted to the Serbian case, and the second to the Croatian. Each part consists of two sections. In the first section, I present selected examples of anti-populist discourse. In the second, I analyze how the visual signs constructed a populist discourse. I do not duplicate any examples, as I wish to focus on the widest possible range of elements in populist discourse.

To investigate the visual discourses, I adapted the visual studies approach. ${ }^{22}$ In the first step, I chose the most frequently reproduced images associated with each protest. ${ }^{23}$ My sources were the popular Croatian and Serbian dailies: Večernji list [Evening Paper] and Danas [Today], respectively. Večernji list is a Croatian daily newspaper published in Zagreb since 1957. It is a non-tabloid newspaper with one of the highest circulations in Croatia, leaning toward a center-liberal viewpoint. Danas is a left-oriented daily newspaper published since 1997 in

${ }^{21}$ The most significant expansion of populism occurred in the mid-2010s, when many populists came to power in East Central Europe. Moreover, the elections of Donald Trump, India's Narendra Modi, Mexico's Andrés Manuel López Obrador, and Brazil's Jair Bolsonaro put populists in power in some of the world's most populous countries. The Brexit referendum in 2016 as well as the popularity of Marine Le Pen's Front Nationale in France, Matteo Salvini's Northern League in Italy, Dutch far-right politician Geert Wilders's Party for Freedom, and the success of the neo-fascist Jobbik party in Hungary are also evidence of a rise in populist sentiment. See Ivan Krastev, "The Strange Death of the Liberal Consensus," Journal of Democracy 18, no. 4 (2007): 53-63, doi: 10.1353/jod.2007.0072; James Dawson and Seán Hanley, "What's Wrong with East-Central Europe? The Fading Mirage of the 'Liberal Consensus,'” Journal of Democracy 27, no. 1 (2016): $20-34$.

22 Gunther Kress and Theo van Leeuwen, Reading Images: The Grammar of Visual Design (London: Routledge, 1996).

${ }^{23}$ It is worth noting that in the media usually only two or three images are reproduced and circulated for each protest. 
Belgrade, but with national circulation. Since the beginning, Danas has maintained a strong independent editorial policy with respect to the government. It is also one of the rare Serbian traditional newspapers that has escaped direct censorship and political control. The key criteria for choosing these two sources were their place of publication, circulation, range, and political orientation.

I analyzed all the issues of both newspapers printed during the period when the protests were under way. I then isolated images that illustrated the news about the protests and accompanied the media discourse about them. On the basis of this research, I compiled a list of images that met two criteria: they directly or indirectly indicated that society was divided into two political camps, the people vs. the elites, and illustrated anti-establishment sentiment. ${ }^{24}$ With the aim of cross-checking the discourses constructed in the traditional media, I also looked at Twitter. I searched for materials on Twitter using hashtags that echoed the main slogans of the protests: \#dostaje [\#enough], \#krivsi [\#guilty], \#1od5miliona [\#1 of5million], and \#poceloje [\#it has started]. The visual material published on Twitter - of which there was not much - largely coincided with the material published in the newspapers. In the next step, I examined the social media profiles of the protests (e.g., Facebook events created by organizers of the protests) and compared them with the discourse created by the participants in the protests and the media coverage of them, in terms of the visual narrative about the manifestations. That allowed me to conclude that the materials I found in the newspapers were representative of that discourse. The overlapping subjects of the photos, the setup of the main shots, among other things, proved that this was a discourse generated by the protests and multiplied by the media, and not vice-versa.

I then moved on to visual content analysis. First, I broke down the visual composition of the images into basic components, treating each component as an independent unit of visual communication. ${ }^{25}$ Second, I decoded the imag-

${ }^{24}$ For the purpose of my research, I do not make a distinction between anti-establishment and anti-elite opinion. Marijana Grbeša and Berto Šalaj understand anti-establishment opinion as a milder version of anti-elite feeling, targeting political ideas that are or already have been in power. Anti-elitism criticizes all elites, and so it also challenges established political models. See Marijana Grbeša and Berto Šalaj, "Populism in Croatia: The Curious Case of the Bridge (Most)," Anali 14, no. 1 (2017): 21-23, doi: 10.20901/an.14.01. From this perspective, the anti-establishment discourse of the Serbian demonstrations is important, because the aim of those inherently people-centric protests was to overthrow an undemocratic regime. In Croatia, the protests were mostly against the corrupt, depraved elites in that country, so they had more of an anti-elitist character.

25 Philip Bell, "Content Analysis of Visual Images," in Handbook of Visual Analysis, ed. Theo van Leeuwen and Carey Jewitt (Los Angeles: Sage, 2008), 10-34. 
ers and situated them into broader semantic systems, social conventions, and codes. Finally, I connected the decoded meanings with the main features of populism outlined above. The research questions I posed were: how is anti-populism expressed during mass demonstrations? What images are used to express anti-populism? What images of populism do anti-populist images reflect? Trying to answer these questions, I noticed an equally interesting phenomenon, which was that populist rhetoric was used by the anti-populist protesters (even if it was not explicit). The initial assumption, that populism opposes various other political phenomena, allowed me to decode expressions where anti-populism appeared. This forced me to pose other research questions: can anti-populist protests employ populist rhetoric themselves? Do the images that articulate opposition to demagogy also employ demagogic tricks? What discourses do such tricks produce? What images express populism, intentionally or not? After decoding the populist and anti-populist expressions transmitted by the protesters, I divided them into thematic groups and applied conceptual labels to them that described their populist nature. Because of formal and legal requirements, I present here only selected images that best illustrate, identify, and describe the visual discourses of populism.

My examination of the parallels between the protests in Croatia and Serbia requires additional clarification. I would like to emphasize that the similarity between the protests lies not so much in their confrontational nature as in their prominence in their respective societies. I perceive the two countries' cultures not as "counter-systems," but as mutually complementary systems of meanings. This approach makes it possible to identify the individual iconospheres of the protests, the parallel way in which they developed, and the extent to which they changed over time. The two countries' iconospheres existed in apparent symbiosis in the twentieth century because for much of it they were under the rule of a single state, Yugoslavia. Thus the frames of reference are similar. Despite significant differences in the experiences that have shaped the Serbian and Croatian societies after the year 2000 , the differences between them, which were painfully apparent in the 1980s and 1990s, are being erased. Therefore, it is legitimate to examine the two cultures as complementary constellations.

For some time now, Croatia has been considered a relatively stable pluralistic democracy. The protests there had a local and temporary character. The nationwide, recurrent protests in Serbia took place at a time when the state and its political structures were gradually moving towards an illiberal politics. That still does not mean the two situations are not complementary. In terms of visual communication, they reflect each other. Moreover, populism is a global 
phenomenon that has affected political communication in both countries in a similar way. The juxtaposition of the two cases shows how the visual discourses of populism have been instrumentalized in a broader way than just locally or nationally.

\section{Anti-Populist Discourses in Serbia}

In her book Populism the Serbian Way, Dubravka Stojanović traces the history of Serbian populism. She writes, somewhat ironically, "I have been getting ready to proclaim Serbia, and perhaps the entire Balkans, the vanguard of populism." 26 She lists the political sources and fathers of Serbian populism in one paragraph: Svetozar Marković, Nikola Pašić, and, after the fall of Yugoslavia, Slobodan Milošević and Aleksandar Vučić. Vučić is viewed as the embodiment of populism in Serbia. A career politician, Vučić was prime minister from 2014 to 2017 and has been Serbia's president since 2017. His political roots are in the Srpska radikalna stranka [Serbian Radical Party], whose leader Vojislav Šešelj was convicted of war crimes by the International Criminal Tribunal for the former Yugoslavia in The Hague. Under President Slobodan Milošević, Vučić was Serbia's minister of information. He co-authored regulations that introduced penalties for anti-government expressions by journalists and blocked citizens' access to foreign television. In 2008, he was among the founders of the Srpska napredna stranka [Serbian Progressive Party] and unexpectedly changed his ideology from the extreme, anti-European Union right to a progressive conservative and pro-EU stand. Political observers accuse him of an autocratic style of governing. ${ }^{27}$ Although Serbia is a parliamentary democracy, almost all governmental decisions are made in the president's office. Vučić controls the state-owned media. ${ }^{28}$ Each election since he took office has been accompanied by reports

${ }^{26}$ Dubravka Stojanović, Populism the Serbian Way (Beograd: Peščanik, 2017), 7.

27 Aleks Eror, "How Aleksandar Vucic Became Europe's Favorite Autocrat," Foreign Policy, March 9, 2018, https://foreignpolicy.com/2018/03/09/how-aleksandar-vucic-became-europes-favorite-autocrat/; "Džihić: Vučić’s False Europeanism Has Been Leading Serbia to Autocracy for Years," European Western Balkans, August 28, 2020, https://europeanwesternbalkans.com/2020/08/28/ dzihic-vucics-false-europeanism-has-been-leading-serbia-to-autocracy-for-years/.

${ }^{28}$ In 2019, Reporters Without Borders stated that Serbia is "a place where practicing journalism is neither safe nor supported by the state." The number of attacks on the media in Serbia was on the rise, including "death threats and inflammatory rhetoric targeting journalists increasingly coming from the governing officials." See "Serbia," Reporters Without Borders, 2019, https://rsf.org/en/ Serbia. 
of serious irregularities from independent observers. Opposition circles accuse him of corruption and nepotism. ${ }^{29}$ Although Vučić's rule cannot be described as authoritarian, in Serbia in recent years we have observed the growth of illiberal policies, i.e., "policies that are enacted (or proposed) by political parties in government with the aim to remain in power indefinitely while maintaining competitive elections. The resulting regimes maintain competitive multiparty elections but are neither democratic nor fully authoritarian." 30

In 2017, a two-month-long protest under the slogan Protiv diktature [Against the Dictatorship] began immediately after Vučić won the presidential election in the first round. In 2018, following a violent assault against an opposition politician by "unknown perpetrators," Belgrade again became the scene of massive peaceful anti-government protests. ${ }^{31}$ Called Stop krvavim košuljama [Stop the Bloody Shirts] or 1 od 5 miliona [One of Five Million], the protests continued with varying intensity until the outbreak of the COVID-19 pandemic in March 2020. The protesters' main demand was the holding of free elections; their list also included freedom of the media, political pluralism, and reform of the electoral laws. The overall aim of the protesters was to show their disapproval of what they perceived as authoritarian populist rule by Aleksandar Vučić.

Although the Serbian protests differed slightly from each other in size and in the participants' social profiles (the first protest was mainly by students, the second one brought together a much wider range of social groups), for this analysis I consider them complementary. Their common denominator was their opposition to the president of Serbia. Similar accusations and demands for Vučić's resignation were articulated during both protests. Their objects were defined in an analogous way, and they employed similar visual rhetoric.

${ }^{29}$ Milenko Vasovic, "Vucic Surfs on Wave of Scandal That Should Drown Him," Balkan Insight, March 3, 2021, https://balkaninsight.com/2021/03/03/vucic-surfs-on-wave-of-scandal-thatshould-drown-him/.

${ }^{30}$ Damir Kapidžić, "The Rise of Illiberal Politics in Southeast Europe," Southeast European and Black Sea Studies 20, no. 1 (2020): 3, doi.10.1080/14683857.2020.1709701. A conceptually broader term applicable to the Serbian political situation is "competitive authoritarian regime." According to Florian Bieber, it captures a combination of two features: "institutional weakness that provides insufficient democratic safeguards, and authoritarian political actors who utilize these weaknesses to attain and retain power." See Florian Bieber, "Patterns of Competitive Authoritarianism in the Western Balkans," East European Politics 34, no. 3 (2018): 338, doi.10.1080/21599165.2018.1490272.

31 The protests in Serbia were also triggered by the many scandals of ruling party members, such as sexual harassment at work, assaults on investigative journalists, plagiarism, and the arrest of a whistleblower who uncovered an arms trade deal in which a shipment allegedly ended up in the hands of ISIS fighters in Yemen, as well as a smear campaign and the unsolved murder of a Kosovo Serb opposition leader, Oliver Ivanović. 
The protesters' anti-populist rhetoric was most apparent in the most frequent image displayed on their banners: Stop Vučić. Simple in form and content, it took the form of a prohibitory road sign: the silhouette of the president with characteristically folded hands, in a red circle crossed by a red bar (Fig. 1).

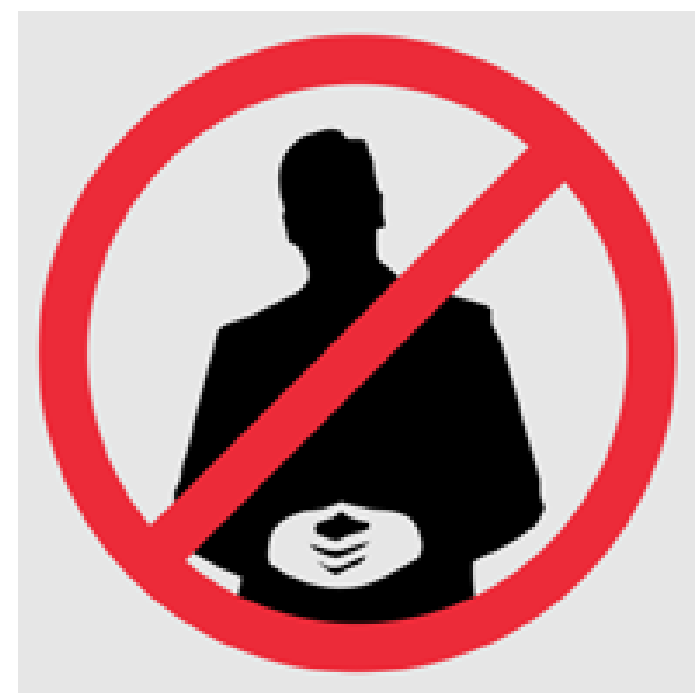

Figure 1. "Stop Vučić."

Source: Wikipedia, https://en.wikipedia.org/wiki/2017_Serbian_protests\#/media/File:2017_serbia_protest_symbol.svg.

Vučić's folded hands seem to be the most important element of the image. According to body language experts, there are many gestures that can signal a leader's devotion to populism. ${ }^{32}$ One of them is folded hands, which are characteristic of people who want to demonstrate their superiority, highly developed leadership qualities and, possibly, authoritativeness. ${ }^{33}$ Known as the "triangle of power," or

32 Erik Page Bucy et al., "Performing Populism: Trump's Transgressive Debate Style and the Dynamics of Twitter Response," New Media \& Society 22, no. 4 (2020): 634-658, doi: 10.1177/1461444819893984; Maria Elizabeth Grabe and Erik Page Bucy, Image Bite Politics: News and the Visual Framing of Elections (New York: Oxford University Press, 2009).

${ }^{33}$ Henry H. Calero, The Power of Nonverbal Communication: How You Act is More Important Than What You Say (Aberdeen: Silver Lake Publishing, 2005). 
the "Merkel diamond" (because it was Angela Merkel's use of this non-verbal signal that made this interpretation popular), the gesture communicates power (the higher the hands, the greater the power). It is an element in the communication game that Vučić plays with his audience. The president is famous for his theatrical gestures, dramatic media appearances, and studied poses. His silhouette on the banner is slightly tilted to the right, which is a pose he takes to suggest that he is listening to his interlocutors. The protesters are criticizing the artificiality of the president's posture and body language, suggesting they are false.

Two other images promoted by the protesters are related to this one. The first is a caricature of the president holding his hands in a similar gesture but this time with his lips exaggerated in size and color (Fig. 2). ${ }^{34}$ The exaggerated lips frequently appeared in the protests. The use of the lips to symbolize President Vučić not only mocked his actual facial features but can also be viewed as a reference to a person who talks a lot and makes a lot of promises. This is how populism is defined in the colloquial sense: paying lip service to social concerns and making unrealistic promises. Reducing Vučić to his lips identifies him with his "eloquence" and rhetorical ability, and with saying things which are often far from reality. In addition, the president wears a black balaclava, by which the protesters alluded to the criminal nature of his actions and indicate that he hides his true identity and intentions.

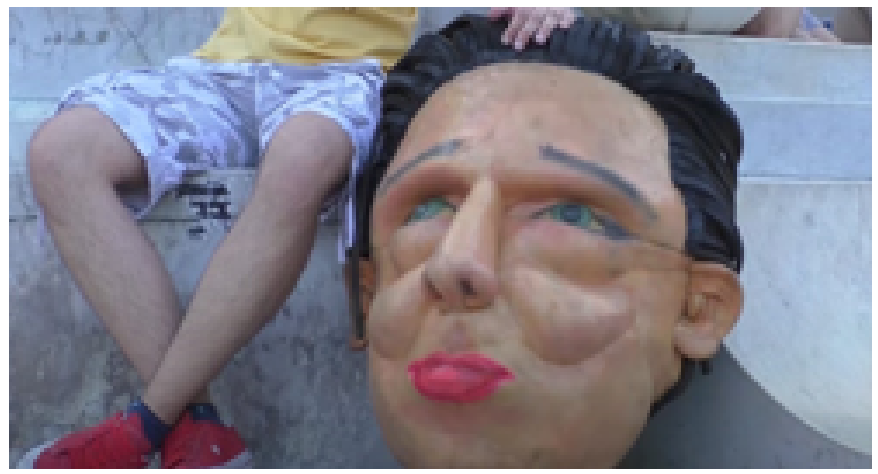

Figure 2. The doll with lips exaggerated in size and color illustrates president Vučić, Belgrade 2019. Photograph by the author.

34 See the images in: Guy De Launey, "Serbia Protests: Anger, Eggs and Chanting at 'Anti-Dictatorship’ Rallies,” BBC News, April 10, 2017, https://www.bbc.com/news/world-europe-39556682. 
A banner depicting President Vučić as Pinocchio ${ }^{35}$ also alludes to his unfulfilled promises and political lies - the long nose is proof of his machinations. Unlike the two banners discussed above, this one makes use of the president's actual photo, thus abandoning the game of guessing who is the intended object of the protesters' criticism. The long nose over which the Pinocchio-Vučić has no control is proof of his lies. The consequences of his lies are not only as plain as the nose on his face, but are obvious to the protesters. Vučić's nose becomes a polygraph for detecting untruth. ${ }^{36}$

Populism is a way of doing politics and a style of political performance. Populist politicians use political mannerisms, recognizable gestures, and facial expressions in their public performances to move about smoothly on the field of power. ${ }^{37}$ Theirs is a performative turn that goes beyond strictly textual data and takes into account the effects of a social actor's actions. Acts of public performance contribute to the power of populism.

\section{Populist Discourse of Protest in Serbia}

Among the photos most frequently reproduced in the media during the 2018 protests known as "One of Five Million" were some showing the massive scale of the gatherings. The aim of these rallies was to voice the protesters' dissatisfaction, but also to show how broadly their sentiments were shared. Demonstrations that fail to attract large crowds of people are usually considered ineffective. Their size, which is meant to prove that the organizers enjoy the support of the masses, is a topic of eternal debate between the protesters and the targets of the demonstrations. The media outlets that favor different political camps usually report different turnouts: they tend to exaggerate the numbers when they support the organizers' objectives and underestimate the numbers when they oppose them. If massive scale is coupled with an impression of spontaneity, i.e., with the image that demonstrations are organized at the grassroots level and express the will of the people, this impacts the perception of the strength and legitimacy of the

35 See photo taken by Darko Vojinovic in Andrew MacDowall, "Serbia's Protests and the Growing Discontent with Western Priorities in the Balkans," World Politics Review, March 5, 2019, https:// www.worldpoliticsreview.com/articles/27566/serbia-s-protests-and-the-growing-discontentwith-western-priorities-in-the-balkans.

${ }^{36}$ In 2018, similar images were used in Thailand during protests against Prime Minister Prayuth Chan-ocha.

37 Benjamin Moffitt, The Global Rise of Populism: Performance, Political Style and Representation (Stanford: Stanford University Press, 2016). 
protests. The visual discourse used in massive protests can be called a "discourse of the masses" (or discourse of quantity).

The Serbian protests in 2017-2020 were indeed the largest since 2000 in that country. Their organizers were well aware of this and eagerly referred to their size. After the first demonstrations, President Vučić declared that the protesters could rally as much as they liked, but that he would never concede to any of the protesters' demands - even if there were five million of them (Serbia's population is seven million). ${ }^{38}$ The organizers of the protests immediately seized upon Vučićs words and turned "One of Five Million" into a slogan. It became the symbol of the protests (Fig. 3) and was used not only on placards and banners during street manifestations, but also as a hashtag or logo on social media.

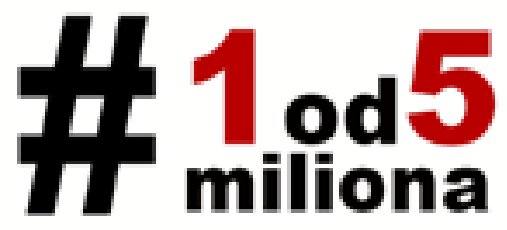

Figure 3. "One of Five Million."

Source: Wikipedia, https://commons.wikimedia.org/wiki/File:1od5miliona.jpg.

However, what we are dealing with here is a shift in populist rhetoric. The stress is still on the individual, who is but one in a group of five million. An individual is part of the group, but his or her interests - even though they may converge with those of co-demonstrators - are as important as the interests of any other participant. They do not dissolve into the mass. The slogan "There Are Five Million of Us" would have a slightly different meaning. Although the slogan seems like only a rhetorical ploy, for populism, understood as a political logic, it is a key concept. The individual is part of the collective; he or she draws strength from its collective energy and shares collective emotions of the crowd with other members of the community.

Although the protests in Serbia were initiated by young people, press coverage of them often featured photos showing the enormous diversity of

38 Beta, "Vučić o protestu: Nek vas se skupi pet miliona, nijedan zahtev neću da ispunim," N1, December 9, 2018, https://rs.nlinfo.com/vesti/a442570-vucic-o-protestu-u-beogradu/. 
the demonstrators in terms of their social group, class, and material wealth. Despite the fact that the protesters marched under one banner of opposition to Vučić's authoritarian government, they also articulated various demands specific to their own social groups, e.g., pensioners: Pljačka penzionera nije reforma [Robbery of Pensioners Is Not a Reform]; workers: Nećemo da budemo jeftina radna snaga [We Don't Want to Be a Cheap Labor Force]; and artists: Kulturom protiv diktature [Culture Against Dictatorship]. This diversity of interests gave rise to what Chantal Mouffe calls "a chain of equivalence." Such a chain is a set of diverse expectations from which a common will is constructed, but which still respects the specificity of diverse struggles. ${ }^{39}$ Mouffe argues that this chain is a feature of left-wing populism, and is a discursive strategy for constructing a political frontier between "the people" and "the oligarchy." What should be emphasized here is the fact that from this perspective, "the people is not a homogeneous subject in which all the differences are somehow reduced to unity." 40 Rather, its strength derives from its heterogeneity and different but equal demands. Laclau emphasizes that "political identities are the result of the articulation (that is, tension) of the opposed logics of equivalence and difference, and the mere fact that the balance between these logics is broken by one of the two poles prevailing beyond a certain point over the other is enough to cause the 'people' as a political actor to disintegrate." 41 In other words, it ceases to be a chain of equivalent demands, but an undifferentiated mass. In left-wing populism, equivalent demands should be integrated under a common motto (or slogan or banner) which reflects the constant tension between the universality and the particularity of the people's demands.

Going beyond particularisms is perfectly expressed by the slogan Svi kao jedan [All as One] (Fig. 4), which is the mirror image of the slogan "One of Five Million." While the latter slogan accentuates the existence of particularisms within a large collectivity, the slogan "All as One" underlines a unity of particularisms, and the merging of individual political interests into one.

The large number of people attending the protests in Serbia was emphasized by slogans such as Nas je ipak više [But There Are More of Us]. The slogans not only stressed the numerical advantage of the demonstrators over the government and indicated that the protests were an expression of a collective will opposed to the establishment, they also conveyed the political division between

\footnotetext{
${ }^{39}$ Mouffe, For a Left Populism, 34.

40 Ibid., 34.

${ }^{41}$ Laclau, On Populist Reason, 200.
} 


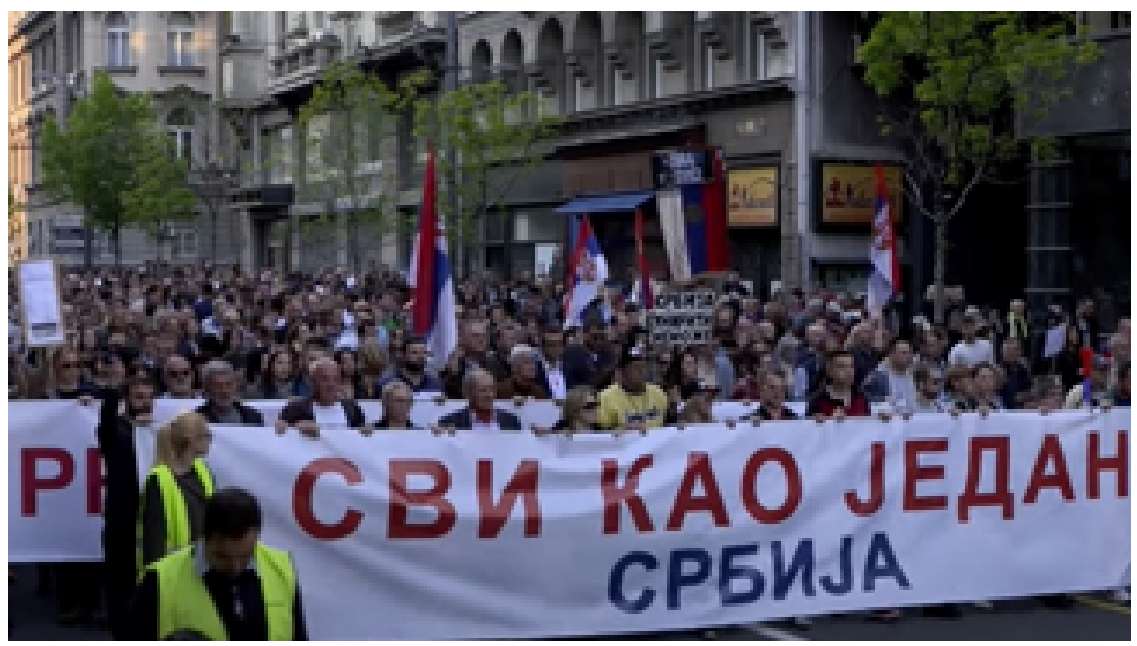

Figure 4. "All as one," Belgrade 2019. Photograph by the author.

the governing and the governed and established a mythical, loosely defined "we". This discourse can be called a "discourse of polarization." It is based on images of social antagonisms, in which one social actor presents itself as a part of society that claims to represent the whole. ${ }^{42}$

This discourse of polarization is undoubtedly populist in nature. Moreover, it is based on collective emotions encouraged by the large number of participants and amplified by media reports on the events that were constantly excited about their number. This confirms the observation that "emotions are performed discursively as if produced by particular images." 43 The discourse of polarization also appears in a graphic reproduced on social media. It is a visual pun on the word "million" (spelled with one "l" in Serbian) - the word was divided into three parts: $m i$ [we] - ili [or] - on [he] (Fig. 5). The "we" were the protesters, and the "he" was clearly Vučić.

42 Ibid., 83.

43 Rebecca Adler-Nissen, Katrine Emilie Andersen, and Lene Hansen, "Images, Emotions, and International Politics: the Death of Alan Kurdi," Review of International Studies 46, no. 1 (2020): 80, doi: 10.1017/S0260210519000317; Simon Koschut et al., "Discourse and Emotions in International Relations," International Studies Review, 19, no. 3 (2017): 501-505, doi: 10.1093/isr/vix033. 


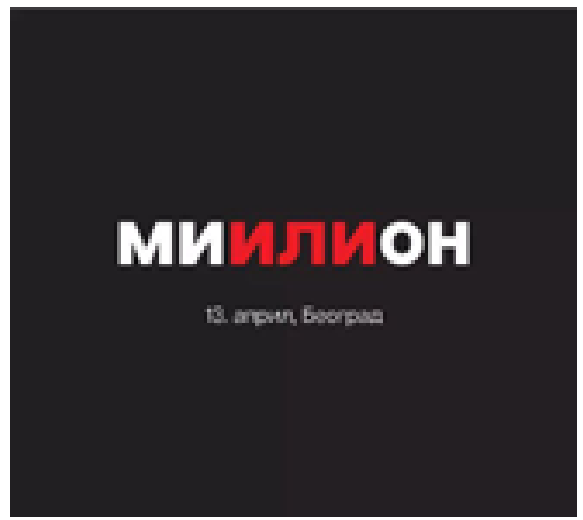

Figure 5. "weORhim, April 13, Belgrade."

Source: Twitter, https://twitter.com/ZezeljMare/status/1105919563638681600/photo/1.

We are dealing here with a simplification of the visual rhetoric of the political space, in which a complex system of difference and determination is replaced by a strong but vaguely defined element: $M i[\mathrm{We}]$. At the opposite pole stands $O n$ [He]. Other versions of this dichotomy remained undefined. In some cases, we can find personalized alternatives in the specific names (e.g., Vučić). Most often the dichotomy is "the people" versus "the oligarchy," or the "working class" versus "the exploiters," or some variant thereof.

Images that clearly identify the opponent, and thus reciprocally define the identity of the protesters, are literal in their messages. One frequently reproduced image from the protests in Belgrade was that of an older woman holding a full-color, handmade banner depicting a heavy boot. The boot symbolizes the authorities, trampling on human figures. The caption at the bottom clearly identifies the figures as the narod, which can be translated into English as either "the nation" or "the people." Although other descriptors of the boot's victims could be used here, such as "entrepreneurs," "humans," or "Serbs," the opposition to the "authorities" that is obviously represented by the boot is the narod/people/ nation. This is a rhetorical device known as totum pro parte, which consists in replacing the name of a part with the name of the whole.

The populist idea is founded on the notion that political power is essentially an instrument for domination. It derives from the origins of participatory democracy and radical utopian visions of "the rule of the people," in which 
political struggles are the struggle of "the people against those in power." Consequently, the main political goal of the populists is to overthrow "the rule of the elite" (oligarchic domination) and ensure the rule of "the people" and "the popular will." In the Serbian protests the protesters point out the sins of the elite quite precisely in such slogans as "Nobody Should Be Hungry and Homeless" and "We Don't Want to Be a Cheap Labor Force." These images talk about the basic needs that the state and its elite are not meeting. They also express the popular feeling of being used by the elite. In other words, they refer to capitalist exploitation.

It is worth drawing attention to one more type of visual material that appears as the articulation of a particular axiological or value system. It is the discourse of vulnerability. Images of this type are very popular all over the world and come in various forms, dependent on the local context. In Serbia, the images contrasted the protesters (or a protester) with law enforcement officers representing the authorities and the state. The most eagerly reproduced images were those in which the protesters were confronted by police in full riot gear. This type of image usually featured a woman standing or sitting in front of the police. In one such photograph from the Belgrade protests we can see a woman wearing the national flag draped over her shoulders, with her hand on her heart. The gesture of putting one's hand on one's heart is associated with a declaration of honesty, of pure intentions, and of meaning something from the bottom of one's heart. The patriotic mini-scene of the woman contrasts with the police officers in full riot gear standing in a line in the background, as if demonstrating supernatural strength. The presence of the police normally "is supposed to guarantee not only order but also a sense of security and trust." 44 Although the woman apparently is not in active conflict with the agents of law and order, the viewer of the photo can clearly see the gap between the two contradictory worlds they represent. One is the world of the heart - the nation -, the other is the world of force and ruling political power.

Another photograph from the One of Five Million protests depicts a woman sitting in front of fully equipped police officers (Fig. 6). Her posture (she sits with her back to the police, head bowed, smoking a cigarette) suggests helplessness, resignation and exhaustion. ${ }^{45}$

44 Steven Balkin and Pauline Houlden, "Reducing Fear of Crime Through Occupational Presence," Criminal Justice and Behavior 10, no. 1 (March 1983): 13-33, doi: 10.1177/0093854883010001002.

45 Twitter sources describes the woman in the picture as the mother of a student arrested during the "One of Five Million” (@\#1od5miliona) protest, Twitter, March 17, 2019, 7:37 p.m., https:// twitter.com/_1od5miliona/status/1107350320315809792/photo/1. 


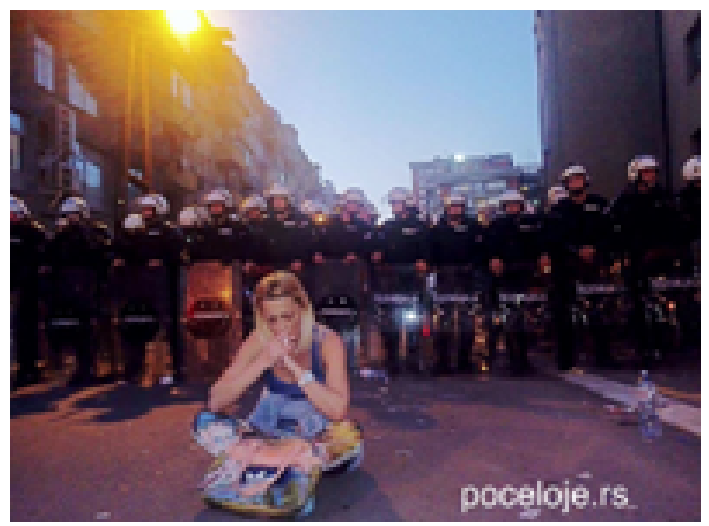

Figure 6. A woman sits in front of a riot police cordon after a standoff during a demonstration against Serbian President Aleksandar Vučić outside the presidential building in Belgrade, 2019. Source: Twitter, https://twitter.com/_1od5miliona/status/1107350320315809792/photo/1.

This photograph even gives the impression that it is a photomontage. The contrast between the unarmed, resigned woman and the armed police emphasizes her weakness and fragility. The discourse of vulnerability is related to the concept of the heartland, introduced to the research on populism by Paul Taggart. In Taggart's conception, the heartland is an ideal "territory of the imagination," 46 in which the following virtues are present: moderation, diligence, ordinariness, straightforwardness, simplicity, clarity, common sense, and tradition. ${ }^{47}$ The heartland takes its power from the heart, it is not necessarily rational or rationalized. The two photos express those values and the virtues associated with the heartland.

\section{Anti-Populism in Croatia}

Much like Aleksandar Vučić in Serbia, Milan Bandić was widely viewed in Croatia as the quintessential populist. ${ }^{48} \mathrm{He}$ was the longest-serving mayor of

46 Taggart, Populism, 95.

47 Ibid., 95-98.

${ }^{48}$ Marijana Grbeša and Berto Šalaj, Dobar loš ili zao? Populizam u Hrvatskoj (Zagreb: TIM Press, 2018); Marija Matić, "Ima li populizma u hrvatskoj politici? Analiza političkog djelovanja Milana Bandića i Željka Keruma," Polemos: časopis za interdisciplinarna istraživanja rata i mira 17, no. 33-34 (2014): 167-181. 
Zagreb, from 2000 until his death in February 2021, with a stormy career that was marred by allegations of clientelism, nepotism and corruption. As mayor, he was often accused of a lack of transparency, and of running wasteful projects in the city (e.g., erecting various fountains and monuments). At the same time, Zagreb suffered from many infrastructure problems, such as inadequate waste management services. Bandić ruled the capital city of Croatia in a direct and highly centralized manner. He sought the support of ethnic minorities, marginalized groups, and the poor. He was investigated several times. He was detained by police in 2014 and was acquitted of graft in 2018. He was still on trial in a second case when he died in 2021, two months before the regular local elections.

Although Zagreb saw many demonstrations protesting his decisions concerning the city (e.g., protests against the redevelopment of the popular historic public square, Cvjetni trg [Flower Market] in Zagreb in 2009-2010), the most impressive act of resistance when it comes to populism was conducted by the Croatian film director Dario Juričan, who was highly critical of Bandić. In a campaign promoting his documentary about Bandić, he officially applied to change his name and surname from Dario Juričan to Milan Bandić - exactly the same as the mayor of Zagreb. ${ }^{49} \mathrm{He}$ then decided to run in the Croatian presidential election of 2019. Election posters with Juričan's image and his "populist" slogans appeared on the streets of the city. Examples are, "whatever they promised you, I offer twice as much!" (Fig. 7) and "corruption for all, not just for them.”

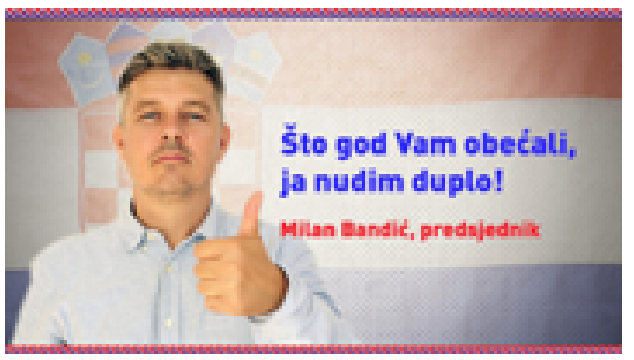

Figure 7. "Whatever they promised you, I offer twice as much!"

Source: Total Croatia News, January 9, 2020, https://www.total-croatia-news.com/politics /40686-dario-jurican.

49 “Dario Juričan promijenio ime u - Milan Bandić!," net.hr, May 31, 2019, https://net.hr/danas/ hrvatska/jurican-promijenio-ime-u-milan-bandic-on-je-rjesenje-a-ne-problem-bilo-je-prirodnoda-se-tako-zovem-2ba4a608-b1c4-11eb-bad7-0242ac140011. 
Juričan's posters were signed “Milan Bandić, President." Under the guise of promoting his film, Juričan (acting a bit like the notorious Borat) ridiculed Mayor Bandić and his populism by impersonating him and ironically exaggerating his populist promises.

Although Juričan's actions were more of a publicity stunt performed by a privileged artist than a mass protest, I recount them to show how he stole the images and slogans of populist vocabulary and aesthetics and co-opted its symbols. His anti-populist sabotage of populism was performed by exaggerating the mayor's content and creating a caricature of it. He subjected populism to severe criticism using keen satirical tools.

\section{Populist Discourse of Protest in Croatia}

As in Serbia, populist rhetoric was present in anti-populist demonstrations in Croatia. Images from a three-part protest against Bandić, held in 2019-2020, will serve here as examples.

It should be emphasized that Zagreb's protests against Bandić were much more modest than the anti-Vučić manifestations in Belgrade. Press sources claim that they attracted between 10,000 and 20,000 people. The protests were local in nature and therefore residents of other Croatian cities were not much interested in them. However, what they have in common with the Serbian protests analyzed earlier in this article is the fact that both Vučić in Serbia and Bandić in Zagreb were considered to be embodiments of populism. Therefore, we can consider the protests parallel research material reflecting both anti-populist and populist strategies.

Three separate anti-Bandić protests took place in 2019-2020, each time under a different slogan: Odstupi! [Resign!], Kriv si! [You Are Guilty!] and Dosta $j e$ ! [Enough!]. The most obviously populist ideas could be found in the "You Are Guilty" demonstration, in which the protesters demanded that the political establishment be held to account for their actions. This discourse can be called "the discourse of the gallows."

As during the protests in Belgrade, the banners depicted a crossed-out face of their object, in this case the mayor. The protesters identified a very specific culprit and emphasized that the masses were against him. Therefore, we are dealing here with both the discourse of numbers and the discourse of polarization. The participants in the demonstration also carried placards with the slogan "You Are Guilty," which was the people's verdict on Bandić's alleged criminal acts. 
Significantly, the judgment here was not passed by a court, but by the crowd. The repetition of this message in the space of protest meant that it was the collective will, the will of the people. It is the people who will judge and declare their enemies guilty. In a sense, this visual discourse brings to mind a biblical image, when the Jewish people were given the choice of whom to acquit and whom to condemn on the eve of Passover. In the case of this protest, the verdict was unambiguous. The "discourse of the gallows" worked to restore to the protesters the power and agency that had been taken away from them by the establishment.

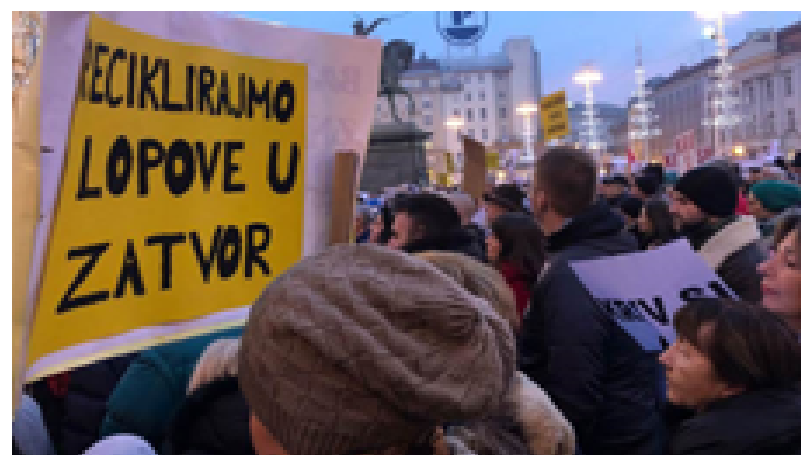

Figure 8. "Let's recycle thieves in jail," Zagreb 2020. Photograph by the author.

In a photo from one of the protests against Bandić (Fig. 8) the discourse of the gallows is expressed by the slogan Reciklirajmo lopove $u$ zatvor [Let's Recycle the Thieves in Jail], which conflates the positive lexicon of a progressive movement ("recycle") with an anti-establishment sentiment ("the thieves in jail"). Here again, a guilty verdict is implied, passed by the crowd, not a court, and in the absence of the defendant. Giving the people the right to make such judgments is a populist move.

The Enough! protest was organized by non-governmental organizations (Siget, Zelena Akcija [Green Action] and Pravo na grad [The Right to the City]). However, it was attended by people representing many different social profiles, whose common denominator was dissatisfaction with the way the city was being managed by its then-mayor. The images most often reproduced by the media evidenced the intersecting and overlapping social identities of the protesters: people of different ages and social and economic statuses. Photos of the protests 
often show people looking tired, exhausted and powerless. We are dealing here with a variation on the theme of vulnerability that is based on a victim feeling threatened and helpless. This type of discourse creates legitimacy for a protest and shows that the dissatisfaction that caused the demonstration is not limited to a narrow social group. The participants in the Belgrade protests were also presented in a similar manner, which stressed their exhausting long-term struggle against a system that was oppressing the common man.

Right-wing populism is based on a belief that it will restore the sovereignty of the people and bring back democracy. It understands sovereignty in a "national" sense, reserved to those who are deemed to be true members of the "nation." By contrast, left-wing populism seeks to construct a "we, the people" who face a common enemy. This requires the establishment of a chain of equivalence between the demands of different social groups. Although left-wing populists and right-wing populists both construct a political frontier, the difference is that the left-wing frontier is not vertical but transversal. The formation of "the people" and their collective will results from the mobilization of shared emotions in defense of equality and social justice. In the left-wing populist strategy, says Chantal Mouffe, "the 'people' is not an empirical referent but a discursive political construction. It does not exist previously to its performative articulation and cannot be apprehended through sociological categories." ${ }^{0}$ She adds that it is not a "mass" in the sense proposed by Gustav Le Bon, where all diversity is blurred. The continuous process of articulating heterogeneous demands, in which the internal diversity of the group is maintained, as well as designating an opponent and dividing society into "us" and "them," are crucial to the process of constructing the left-wing populist concept of "the people."

\section{Conclusion}

Manifestations of populism can be studied at two levels: that of politicians and/or political parties, and that of the voters. These two levels are interrelated and stimulate each other. The populism of politicians involves a dichotomous approach to reality, usually coupled with a strong emphasis on anti-elitism, conspiracy theories, and the creation of an enemy. It is often based on scapegoating. An inherent element of the populism of politicians is a promise to improve the people's current situation. They stress that without the support of the people,

50 Mouffe, For A Leftist Populism, 34. 
the changes they promise cannot happen. On the other hand, the populism of the voters involves three different attitudes: a critical attitude toward the political elite and the political system, political cynicism (the conviction that politics does not serve the common good but only particular interests), and political alienation, i.e., a feeling of powerlessness and alienation from the sphere of politics. All of these attitudes greatly enhance the susceptibility of "the people" to populism. ${ }^{51}$

This study has attempted to show that the rhetoric of anti-populist demonstrations tracks populist rhetoric very closely. The demonstrators employ it intelligently and decode it as they protest against the populist rhetoric of the politicians. Images that criticize the politicians' populist rhetoric most often capture it in one clear symbol, such as a politician's lips, a liar's nose, or contrived body language. The visual articulations of anti-populism are also artistic performances. Their message tends to be less straightforward than the slogans: they adopt codes and content, they paraphrase, they impersonate and use wordplay, and they even tweak hegemonic messages with culture jamming. Their greater complexity suggests that they are aimed at recipients with more advanced cultural skills.

However, anti-populist protests are not free from the elements of the populist repertoire. Excitement about "the people" and emotional resistance to elitism are also present, albeit differently motivated. When left-wing circles make use of the concept of "the people," they mean something quite different than right-wing populists who use the same phrase. A street protest is a stage on which many different actors appear. The spontaneity, unpredictability and polyphonic nature of street demonstrations mean that the overriding goal is expressed in many different ways, using various images. Populist images reflect the mass character of the demonstrators and strengthen their feelings of unity. At the same time they construct a clear dichotomy between "us" and "them," between "the dominated" and "the dominant." They also present the protest as expressing a collective will. The visual images that most frequently appear guide the collective emotions of a crowd. They stimulate a desire to hold those in power to account and often influence the further course of the demonstration.

Politicians perceive the so-called populist movement as an opportunity to prove their extraordinary competence and thus confirm their own status as saviors

${ }^{51}$ Krzysztof Jasiecki, "Polska u progu Unii Europejskiej: referendum akcesyjne a deficyt demokratyczny," in Populizm a demokracja, ed. Radosław Markowski (Warszawa: Instytut Studiów Politycznych PAN, 2004), 95-122. 
of the people. A similar mechanism can be observed among the participants in a mass demonstration. The energy and dynamic intensification of the demonstration generates a wave of emotion with promises to overthrow the government, hold it to account and introduce a new order. Like their opponents among the establishment politicians, charismatic leaders of such protests naturally arise to take on the role of saviors. Images are helpful in that process. 